\title{
Geology
}

\section{Zircon $\mathrm{U}-\mathrm{Pb}$ and $\mathrm{Hf}$ isotope constraints on the Mesozoic tectonics and crustal evolution of southern Tibet}

Mei-Fei Chu, Sun-Lin Chung, Biao Song, Dunyi Liu, Suzanne Y. O'Reilly, Norman J. Pearson, Jianqing Ji and Da-Jen Wen

Geology 2006;34;745-748

doi: $10.1130 / G 22725.1$

Email alerting services

click www.gsapubs.org/cgi/alerts to receive free e-mail alerts when new articles cite this article

Subscribe

Permission request click www.gsapubs.org/subscriptions/ to subscribe to Geology

click http://www.geosociety.org/pubs/copyrt.htm\#gsa to contact GSA

Copyright not claimed on content prepared wholly by U.S. government employees within scope of their employment. Individual scientists are hereby granted permission, without fees or further requests to GSA, to use a single figure, a single table, and/or a brief paragraph of text in subsequent works and to make unlimited copies of items in GSA's journals for noncommercial use in classrooms to further education and science. This file may not be posted to any Web site, but authors may post the abstracts only of their articles on their own or their organization's Web site providing the posting includes a reference to the article's full citation. GSA provides this and other forums for the presentation of diverse opinions and positions by scientists worldwide, regardless of their race, citizenship, gender, religion, or political viewpoint. Opinions presented in this publication do not reflect official positions of the Society.

\section{Notes}

Geological Society of America

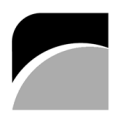

THE

GEOLOGICAL

SOCIETY

OF AMERICA 


\title{
Zircon $\mathrm{U}-\mathrm{Pb}$ and $\mathrm{Hf}$ isotope constraints on the Mesozoic tectonics and crustal evolution of southern Tibet
}

\author{
$\left.\begin{array}{l}\text { Mei-Fei Chu } \\ \text { Sun-Lin Chung* }\end{array}\right]$ - Department of Geosciences, National Taiwan University, Taipei, Taiwan \\ Biao Song Dunyi Liu - Institute of Geology, Chinese Academy of Geological Sciences, Beijing, China \\ Suzanne Y. O'Reilly ] Australian Research Council National Key Centre for Geochemical Evolution and Metallogeny of \\ Norman J. Pearson $]$ Continents (GEMOC), Department of Earth and Planetary Sciences, Macquarie University, \\ Sydney, Australia
}

Jianqing Ji School of Earth and Space Sciences, Peking University, Beijing, China

Da-Jen Wen Department of Geosciences, National Taiwan University, Taipei, Taiwan

\section{ABSTRACT}

The first in situ $\mathrm{Hf}$ and $\mathrm{U}-\mathrm{Pb}$ isotope analyses of zircon separates from Mesozoic granites in southern Tibet identify a significant, previously unknown stage of magmatism. Igneous zircons $(n=34)$ from a granite within the Gangdese batholith show a weighted mean ${ }^{206} \mathrm{~Pb} /{ }^{238} \mathrm{U}$ age of $188.1 \pm 1.4 \mathrm{Ma}$ and $\varepsilon_{\mathrm{Hf}}(\mathrm{T})$ (the parts in $10^{4}$ deviation of initial $\mathrm{Hf}$ isotope ratios between the zircon sample and the chondritic reservoir) values between +10.4 and +16.8, suggesting predominantly Early Jurassic intrusive activity with a juvenile mantle contribution. Of 40 inherited zircons from two Cretaceous S-type granites in the northern magmatic belt, 23 delineate a slightly older ${ }^{206} \mathrm{~Pb} /{ }^{238} \mathrm{U}$ age cluster between 188 and 210 Ma. These zircons have $\varepsilon_{\mathrm{Hf}}(\mathrm{T})$ values from -3.9 to -13.7 , yielding crustal Hf model ages from ca. 1.4 to 2.1 Ga, suggesting a major episode of crustal growth in Proterozoic time and remelting of this crust in Early Jurassic time. Combining these with literature data, we interpret the Jurassic Gangdese magmatism as an early product of the Neo-Tethyan subduction that played a long-lasting role in the tectonic evolution of southern Tibet prior to the India-Asia collision.

Keywords: zircon, Hf isotope, U-Pb dating, Tibet, Neo-Tethyan subduction.

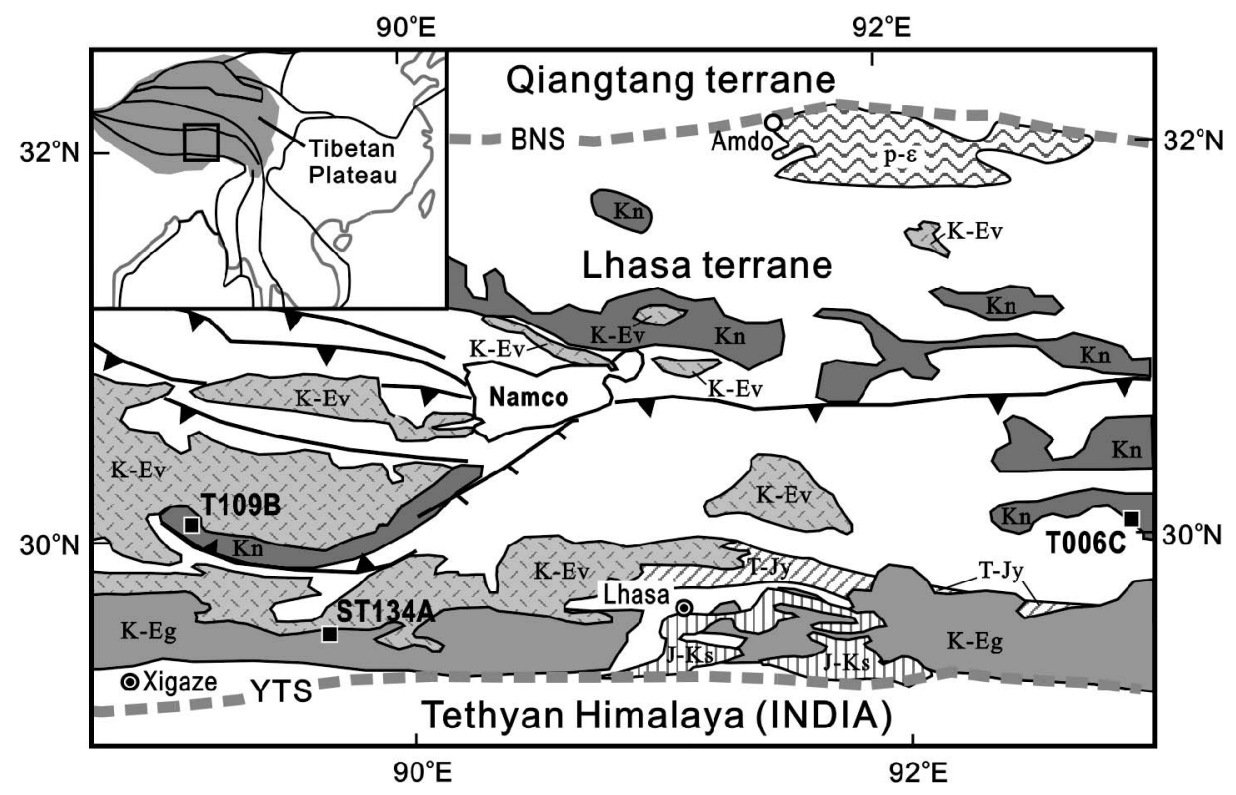

Figure 1. Simplified geologic map showing sample localities and distribution of major magmatic suites of Mesozoic ages in Lhasa terrane, southern Tibet (Pan et al., 2004). Inset denotes principal terrane boundaries in East Asia. BNS-Bangong-Nujiang suture; YTSYarlung-Tsangpo suture; T-Jy-Triassic-Jurassic Yeba Formation; J-Ks-JurassicCretaceous Sangri Group; $\mathrm{Kn}-$ Cretaceous granitoids in northern magmatic belt; $\mathrm{K}-\mathrm{Eg}-$ Cretaceous-Eocene Gangdese batholiths; K-Ev-Cretaceous-Eocene volcanic rocks; $p-\varepsilon-$ Amdo gneiss.

\section{INTRODUCTION}

There is now general consensus that Tibet assembled by the accretion of a series of Gondwana-derived terranes to Asia in Mesozoic time (cf. Yin and Harrison, 2000). Numerous studies over the past few decades have helped develop an understanding of the IndiaAsia collision and related Cenozoic tectonic processes, which led to the formation of the Himalayas and the Tibetan Plateau. However, relatively little work has focused on the precollisional geology. This is particularly true for southern Tibet, which comprises essentially the Lhasa and Tethyan Himalaya terranes, north and south of the Yarlung-Tsangpo suture zone, respectively (Fig. 1); the precollisional configuration and crustal (and lithospheric) evolution of both terranes remain unclear. Thus, models proposed for Cenozoic Tibetan tectonic evolution have been based on assumptions of initial conditions with scarce data.

As part of our study of trans-Himalayan magmatism, we report the first in situ $\mathrm{U}-\mathrm{Pb}$ dating and $\mathrm{Hf}$ isotope analyses of zircon separates from three granites in the Lahaska terrene using the sensitive high-resolution ion microprobe (SHRIMP) and laser ablation microprobe-multicollector-inductively coupled plasma mass spectrometry (LAM-MCICPMS), respectively. The results allow us to identify a significant stage of magmatic activity in southern Tibet during the Early Jurassic. This finding provides new constraints on the precollisional history and crustal evolution of the Lhasa terrane, and has implications for better delineating the Cenozoic or postcollisional tectonomagmatism in the region.

\section{GEOLOGIC BACKGROUND AND SAMPLES}

Tibet is composed of four east-westtrending continental fragments or terranes: from north to south, these are the SongpanGanze, Qiangtang, Lhasa, and Tethyan Himalaya, separated by the Jinsha, Bangong-

\footnotetext{
* E-mail: sunlin@ntu.edu.tw.
} 
Nujiang, and Yarlung-Tsangpo suture zones representing the Paleo-Tethyan, MesoTethyan, and Neo-Tethyan Ocean relicts, respectively (Yin and Harrison, 2000). The Lhasa terrane is believed to have dispersed from Gondwana during the Permian or Triassic (e.g., Allègre et al., 1984; Chang et al., 1986); it then drifted northward and finally collided with the Qiangtang terrane in the Early Cretaceous (Kapp et al., 2005b). The terrane is bounded to the south by the Yarlung-Tsangpo suture zone (Fig. 1), resulting from closure of the Neo-Tethyan Ocean due to the continental collision between India and Asia (Yin and Harrison, 2000).

The Lhasa terrane consists primarily of Paleozoic and Mesozoic sedimentary strata associated with igneous rocks (Pan et al., 2004). The latter include volcanics and widespread intrusive bodies that have been divided into two suites (Fig. 1): a southern Gangdese belt comprising Late Cretaceous and Paleogene batholiths dominated by dioritic and I-type compositions (Debon et al., 1986), and a northern magmatic belt that includes Early Cretaceous peraluminous, or S-type, granitoids (Xu et al., 1985; Harris et al., 1990). While the Gangdese magmatism is widely ascribed to the northward subduction of the Neo-Tethyan oceanic lithosphere under the Lhasa terrane, the petrogenesis of the northern magmatic belt is debated (Kapp et al., 2005b, for review).

As part of a more detailed, ongoing investigation of Gangdese batholiths (Wen et al., 2003, 2005), this paper reports a comparative study of the northern magmatic belt. Of $\sim 30$ granitic samples collected from this belt, 2 (T006C and T109B; Fig. 1) were chosen for zircon analysis. Zircons from sample T006C (biotite granite) are pink or light purple and $\sim 100-250 \mu \mathrm{m}$ long; crystal forms vary from long to short prismatic and the mean length/ width ratio is $\sim 2.7$. Zircons from sample T109B (two-mica granite) are mostly transparent, pink to yellow, and $\sim 50-300 \mu \mathrm{m}$ long, marked by more variable forms, from long to short prismatic to rounded, and a smaller mean length/width ratio of $\sim 1.9$. A biotite granite (ST134A) from the central Gangdese belt (Fig. 1) unexpectedly yielded Jurassic zircon $\mathrm{U}-\mathrm{Pb}$ ages: zircons from this sample are yellowish-pink and $\sim 40-150 \mu \mathrm{m}$ long, with crystal forms from short prismatic to rounded and a mean length/width ratio of $\sim 2.1$.

\section{ANALYTICAL METHODS}

Zircons were separated from $\sim 5 \mathrm{~kg}$ granitic samples by heavy-liquid and magnetic methods. Cathodoluminescence images (taken at the Beijing SHRIMP Center, Institute of Geology, Chinese Academy of Geological Sciences) were used to check the internal structures of individual zircon grains and to select positions for analyses (GSA Data Repository Fig. DR $1^{1}$ ). In situ zircon U-Pb dating was carried out at the center using the SHRIMP II system, following the analytical procedures reported in Chung et al. (2003). In situ Hf isotope measurements were subsequently performed on the dated spots within the zircons using LAM-MC-ICPMS (Australian Research Council National Key Centre for Geochemical Evolution and Metallogeny of Continents, Macquarie University). The diameter of the laser-ablated craters is $\sim 50 \mu \mathrm{m}$, about twice that of the spots made by SHRIMP dating. The analytical procedures were generally as reported in Griffin et al. (2002), with a New Wave UP193 Excimer laser being attached to a Nu Plasma MC-ICPMS.

Whole-rock granite samples were powdered and measured for major and trace element and $\mathrm{Sr}-\mathrm{Nd}$ isotope compositions; the analytical methods and results are in Table DR1 (see footnote 1). The zircon $\mathrm{U}-\mathrm{Pb}$ dating and $\mathrm{Hf}$ isotope results are summarized in Tables DR2 and DR3 (see footnote 1), respectively. The $\boldsymbol{\varepsilon}_{\mathrm{Hf}}(\mathrm{T})$ values (the parts in $10^{4}$ deviation of initial Hf isotope ratios between the zircon sample and the chondritic reservoir) and $\mathrm{T}_{\mathrm{DM}} \mathrm{C}^{\mathrm{C}}$ (the zircon $\mathrm{Hf}$ isotope crustal model ages based on a depleted-mantle source and an assumption that the protolith of the zircon's host magma has the average continental crustal ${ }^{176} \mathrm{Lu} /{ }^{177} \mathrm{Hf}$ ratio of 0.015$)$, were calculated following Griffin et al. (2002), using the ${ }^{176} \mathrm{Lu}$ decay constant adopted in Blichert-Toft and Albarède (1997). Our conclusions would not be significantly affected if alternative decay constants proposed by more recent studies were used.

\section{ANALYTICAL RESULTS}

\section{Zircon U-Pb Ages}

Zircons from both granites of the northern belt are largely inherited. In sample T006C, which has an $\mathrm{SiO}_{2}$ content of $67 \mathrm{wt} \%$, ASI of 1.07 , and an $\mathrm{Rb}-\mathrm{Sr}$ mineral isochron age of $141 \pm 2$ Ma (Table DR1; see footnote 1), none of the zircons dated (22 analyses for 22 grains, Table DR2; see footnote 1) yielded U$\mathrm{Pb}$ ages in accord with the crystallization age of the rock. These $\mathrm{U}-\mathrm{Pb}$ results, which plot along the concordia line except for three analyses (Fig. DR2; see footnote 1), show a large age range from ca. 188 to $1860 \mathrm{Ma}$.

Zircons from sample T109B show similar characteristics in U-Pb ages (21 analyses for 18 grains, Table DR2), which range from ca. 121 to 1750 Ma. Only the youngest analysis is coeval with the crystallization age (ca. 120

${ }^{1}$ GSA Data Repository item 2006156, zircon U$\mathrm{Pb}$ age and $\mathrm{Hf}$ isotope data, with geochemical compositions of the host rocks, is available online at www.geosociety.org/pubs/ft2006.htm, or on request from editing@geosociety.org or Documents Secretary, GSA, P.O. Box 9140, Boulder, CO 80301, USA.

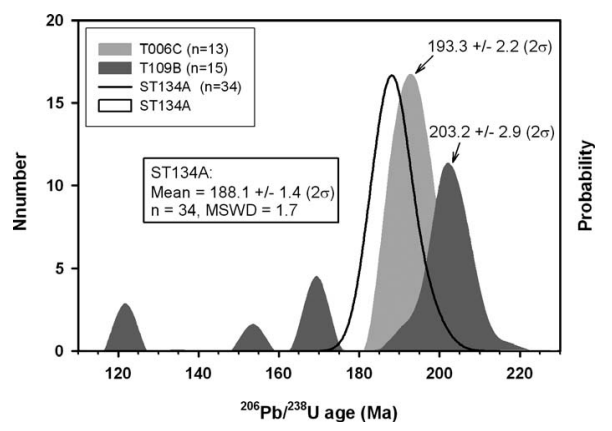

Figure 2. Relative probability plots of zircon ${ }^{206} \mathrm{~Pb} /{ }^{238} \mathrm{U}$ ages for three samples studied, combined with histogram of analytical values for sample ST134A. MSWD-mean square of weighted deviates.

Ma, Table DR1). In this sample, most inherited zircons contain higher concentrations of $\mathrm{U}$ (>800 to $\sim 4000 \mathrm{ppm}$ ) and $\mathrm{Th}(>400$ to $\sim 3000 \mathrm{ppm}$ ) relative to the previous sample T006C but similar $\mathrm{Th} / \mathrm{U}$ ratios $(\sim 1.1-0.3)$. This sample also has a more evolved wholerock composition, with $\mathrm{SiO}_{2}$ of $73 \mathrm{wt} \%$ and ASI of 1.17, coupled with higher $U$ abundance (6.2 ppm, Table DR1), than the previous sample.

Zircons from both samples show clusters in ${ }^{206} \mathrm{~Pb} /{ }^{238} \mathrm{U}$ ages between ca. 188 and $210 \mathrm{Ma}$ (Table DR2). About half of the zircons in samples T006C $(\mathrm{n}=13)$ and T109B $(\mathrm{n}=10)$ define age clusters at $193.3 \pm 2.2 \mathrm{Ma}(95 \%$ confidence; mean square of weighted deviates $[\mathrm{MSWD}]=1.5)$ and $203.2 \pm 2.9 \mathrm{Ma}$ $(\mathrm{MSWD}=4.5)$, respectively.

In contrast, 34 zircons dated from sample ST134A are all magmatic and yielded a weighted mean of ${ }^{206} \mathrm{~Pb} /{ }^{238} \mathrm{U}$ age of $188.1 \pm$ $1.4 \mathrm{Ma}(95 \%$ confidence; MSWD = 1.7), slightly younger than the two clusters but overlapping the total age range observed in the two granites from the northern belt (Fig. 2 ). These zircons have relatively low and uniform $\mathrm{U}$ and Th concentrations $(\sim 100-150$ and 70-100 ppm, respectively, Table DR2; see footnote 1), yielding uniform $\mathrm{Th} / \mathrm{U}$ ratios $(\sim 0.5-1.0)$ typical of an igneous origin (Hoskin and Black, 2000). This U-Pb date is therefore interpreted to represent the crystallization age of the sample that, together with Hf isotope data and whole-rock geochemistry (see following), suggests previously unrecognized plutonism in the Early Jurassic, significantly older than that in the surrounding Late Cretaceous to Paleogene Gangdese batholiths.

\section{Hf Isotope Data}

Of the 34 dated zircons from sample ST134A, 20 were analyzed for Hf isotope ratios. They yielded $\boldsymbol{\varepsilon}_{\mathrm{Hf}}(\mathrm{T})$ values from +10.4 to +16.8 that straddle the mean value of the depleted mantle at $188 \mathrm{Ma}$ (Fig. 3A). This differs remarkably from the crustal-type Hf isotope composition of the Jurassic inherited zircons from the two granites in the northern 

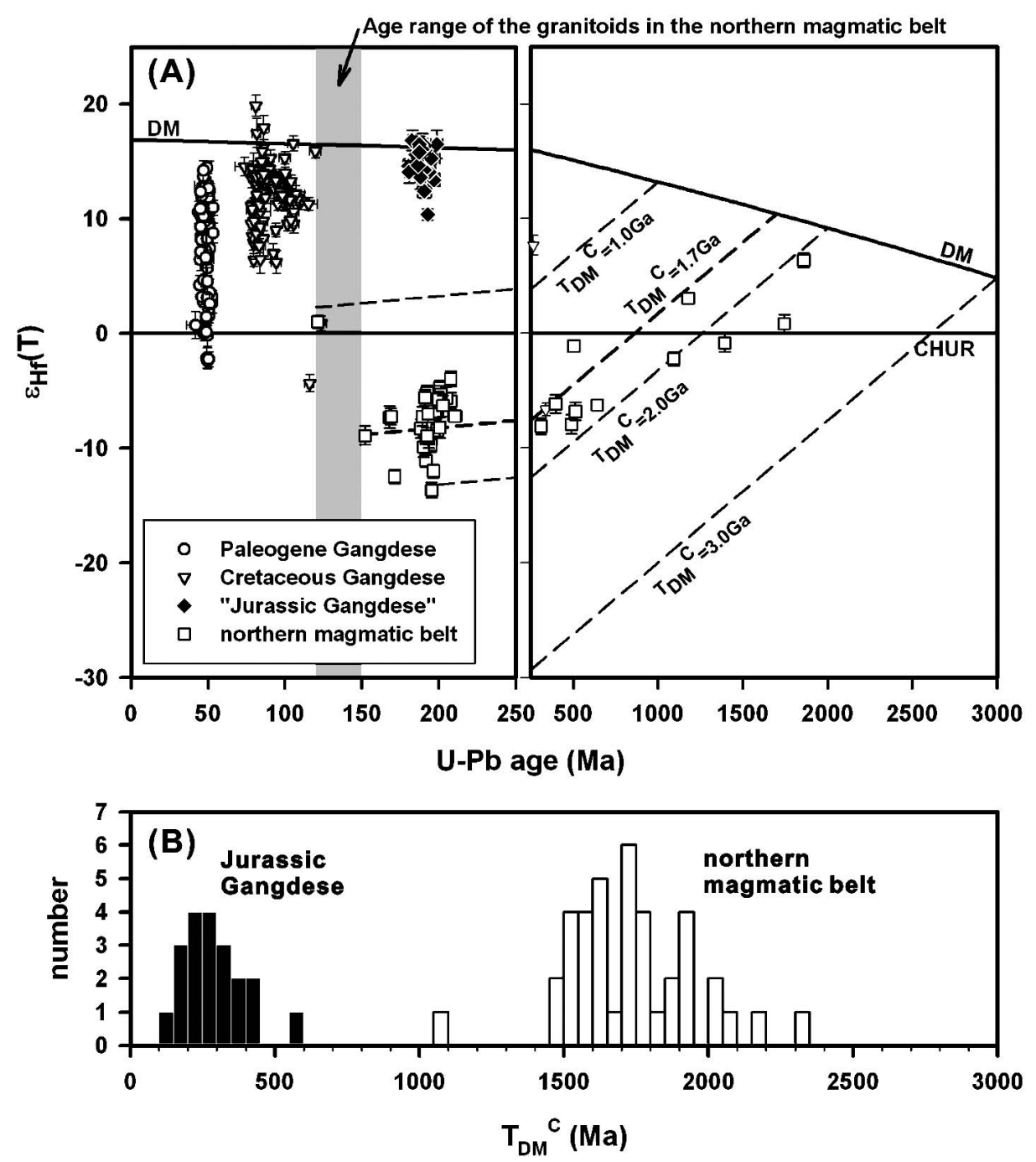

Figure 3. A: Plots of $\varepsilon_{\mathrm{Hf}}(\mathrm{T})$ (the parts in $10^{4}$ deviation of initial Hf isotope ratios between the zircon sample and the chondritic reservoir) vs. U-Pb ages. B: Histogram of $\mathrm{T}_{\mathrm{DM}}{ }^{\mathrm{C}}$ (zircon $\mathrm{Hf}$ isotope crustal model age) for zircons of Jurassic Gangdese (sample ST134A) and northern magmatic belt (samples T006C and T109B). For comparison, our unpublished data for Cretaceous and Paleogene Gangdese zircons are also plotted in A. Calculation details regarding $\mathrm{T}_{\mathrm{DM}}{ }^{\mathrm{C}}$ ages and notations of chondritic uniform reservoir (CHUR) and depleted-mantle (DM) curves are in Table DR3 (see footnote 1).

magmatic belt that exhibit $\boldsymbol{\varepsilon}_{\mathrm{Hf}}(\mathrm{T})$ values from -11.1 to -4.7 (T006C) and from -13.7 to -3.9 (T109B), respectively. The only comagmatic grain (ca. $121 \mathrm{Ma}$ ) in sample T109B shows $\boldsymbol{\varepsilon}_{\mathrm{Hf}}(\mathrm{T})$ of +1 , suggesting a magma source that has an isotope composition between the mantle and crustal values. The remaining inherited zircons, i.e., those with U$\mathrm{Pb}$ ages between ca. 300 and $1860 \mathrm{Ma}$, show heterogeneous $\varepsilon_{\mathrm{Hf}}(\mathrm{T})$ values from +6.4 to -12.5 (Fig. 3A), recording the isotopic variations in the multiple magmatic events that took place in the Lhasa terrane.

\section{DISCUSSION}

Crustal Evolution of the Lhasa Terrane

Zircons can effectively preserve the initial Hf isotope ratios of their host magmas, thus allowing their Hf isotope compositions to be utilized in much the same way as whole-rock $\mathrm{Nd}$ isotopes have been utilized as a powerful within the Lhasa terrane between the late $\mathrm{Pa}$ leoproterozoic and early Mesoproterozoic.

The zircon Hf isotope evidence of an important Proterozoic period of crustal growth in the Lhasa terrane is consistent with the wholerock $\mathrm{Nd}$ model ages of the two granites from the northern belt (ca. 1470-1710 Ma, Table DR1) and available literature data. The latter include (1) whole-rock Nd model ages (ca. 1560-2100 Ma) reported for CarboniferousNeogene sedimentary rocks (Harris et al., 1990), (2) Nd model ages (ca. 1240-1650 Ma) for the Amdo gneiss (Harris et al., 1990), the only basement complex exposed in the northern margin of the Lhasa terrane (Fig. 1), (3) Nd model ages (ca. 900-2190 Ma) for the Nyainqentanglha Range granitoids (Kapp et al., 2005a), and (4) substantial amounts of Proterozoic detrital zircons from a Carboniferous sandstone and sediments along the bank of the Yarlung-Tsangpo River (Liang et al., 2004). These allow us to conclude that the Lhasa terrane underwent a major stage of crustal formation in the Proterozoic, and this crust was remelted in the Early Jurassic, producing abundant igneous zircons that were later captured by the Cretaceous S-type plutonism in the northern magmatic belt.

\section{Jurassic Gangdese and Related Magmatism}

The zircon $\mathrm{U}-\mathrm{Pb}$ ages and $\mathrm{Hf}$ isotopes of sample ST134A strongly suggest Early Jurassic intrusive activity that was marked by a dominant contribution from a juvenile mantle source. Although the data are insufficient for a detailed petrogenetic analysis, a comparison of the geochemical systematics of sample ST134A with those of nearby CretaceousPaleogene Gangdese granitoids (e.g., sample ST104A, Table DR1; see footnote 1) may help us explore the tectonic setting associated with the Jurassic magmatism. These two samples show relative enrichments in large ion lithophile and light rare earth elements, depletions in high field strength elements, and juvenile mantle-type $\mathrm{Sr}$ and $\mathrm{Nd}$ isotope ratios (Table DR1). Isotopic similarity is also revealed by the $\boldsymbol{\varepsilon}_{\mathrm{Hf}}(\mathrm{T})$ values of the igneous zircons from sample ST134A and the Cretaceous Gangdese granitoids (Fig. 3A). A common tectonic setting, i.e., an active convergent margin associated with northward subduction of NeoTethyan oceanic lithosphere under the Lhasa terrane, is therefore inferred for the Early Jurassic magmatism.

Volcanic rocks intercalated with Jurassic sedimentary strata have been reported in the southern Lhasa terrane. These are andesitic to rhyolitic rocks from the uppermost TriassicMiddle Jurassic Yeba Formation (Yin and Grant-Mackie, 2005) and the Upper JurassicLower Cretaceous Sangri Group (Pan et al., 2004); both are exposed in the eastern Gangdese region (Fig. 1) and are conventionally re- 
garded as products of convergent margin magmatism, although few detailed petrologic and geochemical investigations exist. Additional information that supports the widespread occurrence of Jurassic magmatism in the southern Lhasa terrane includes (1) abundant Jurassic detrital zircons $\left({ }^{206} \mathrm{~Pb} /{ }^{238} \mathrm{U}\right.$ ages $=194-$ $169 \mathrm{Ma} ; 24$ of 60 analyses) in a Cretaceous tuffaceous sandstone from the Gangdese belt (Liang et al., 2004), (2) the common presence of Jurassic zircons in the Yarlung-Tsangpo River sediments that show ${ }^{206} \mathrm{~Pb} /{ }^{238} \mathrm{U}$ ages of ca. $182-175 \mathrm{Ma}$ and $\boldsymbol{\varepsilon}_{\mathrm{Hf}}(\mathrm{T})$ values to +15 (Liang et al., 2004), and (3) the Jurassic inherited zircons (ca. 204-181 Ma) in the Nyainqentanglha Range granitoids (Kapp et al., 2005a).

We therefore propose that within the southern Lhasa terrane, there were three discrete stages of Gangdese arc magmatism in the Jurassic, Cretaceous, and Paleogene. Within this framework, the Neo-Tethyan subduction system must have played a crucial and longlasting role in the tectonic evolution of the Lhasa terrane, from when the terrane was drifting northward from Gondwana until its final assembly with India. Whereas the latter two stages of the Gangdese magmatism appear to be separated by a magmatic gap from ca. 80 to $65 \mathrm{Ma}$ (Chung et al., 2005; Wen et al., 2005), the temporal and spatial relationships between the former two stages remain relatively unknown and require more investigation.

\section{Further Tectonic Implications}

By the Early Jurassic, extensive and dominantly crustally derived magmatism may have already been active in the northern part of the Lhasa terrane, as evidenced by our results from the two S-type granites and a study by Kapp et al. (2005a) on the Nyainqentanglha Range granitoids. The latter work, albeit focused on the late Cenozoic exhumation and thermal history of the Nyainqentanglha massif, reported a total of $459 \mathrm{U}-\mathrm{Pb}$ analyses for zircons from more than 40 granitoid samples that identify an age peak ca. $210 \mathrm{Ma}$ (Kapp et al., 2005a). Our sample T109B, which yields the zircon age cluster of ca. $203 \mathrm{Ma}$, was collected near the southern extension of the Nyainqentanglha Range (Fig. 1). The Jurassic and Cretaceous Gangdese magmatic activities, predating and postdating the final assembly of the Lhasa and Qiangtang terranes in Early Cretaceous time (Kapp et al., 2005b), respectively, are both associated with S-type magmatism in the northern Lhasa terrane that may reflect substantial crustal remelting there. Such an association not only reinforces the suggestion of a common tectonic setting for the two Gangdese magmatic stages, but also provides clues about the long-term debate on the petrogenesis of the northern magmatic belt, which has been attributed to (1) anatexis of thickened crust during the continental collision of the Lhasa and Qiangtang terranes (Xu et al., 1985; Pearce and Mei, 1988), (2) crustal melting caused by asthenospheric upwelling after the Lhasa-Qiangtang collision (Harris et al., 1990), or (3) low-angle northward subduction of the Neo-Tethyan oceanic slab (Coulon et al., 1986; Zhang et al., 2004; Kapp et al., 2005b). Kapp et al. (2005b) suggested that this low-angle subduction provided the driving force for a large-scale northward continental underthrusting during the Lhasa-Qiangtang collision. Our observations do not support the former two scenarios, but are not at odds with the third interpretation. If this is the case, the low-angle or flat-slab subduction should have taken place before and after the LhasaQiangtang collision. How such a long-lasting subduction system evolved in the Neo-Tethys and how it interacted with the LhasaQiangtang and then with the India-Asia continental collisions requires further detailed studies, which will elucidate the complex accretionary and collisional orogenic processes that operated in what is now the southern Tibetan Plateau.

\section{ACKNOWLEDGMENTS}

We thank J. Aitchison, P. Kapp, and W.L. Griffin for very constructive reviews and suggestions, H.Y. Lee, Q. Qian, and Mary Yeh for help in the field, and T.-Y. Lee and C.-H. Lo for inputs at various stages of this study, which benefited from financial supports by the National Science Council, Taiwan.

\section{REFERENCES CITED}

Allègre, C.J., and 34 others, 1984, Structure and evolution of the Himalaya-Tibet orogenic belt: Nature, v. 307, p. 17-22.

Blichert-Toft, J., and Albarède, F., 1997, The Lu-Hf isotope geochemistry of chondrites and the evolution of the mantle-crust system: Earth and Planetary Science Letters, v. 148, p. 243-258.

Chang, C., and 26 others, 1986, Preliminary conclusions of the Royal Society and Academia Sinica 1985 Geotraverse of Tibet: Nature, v. 323, p. 501-507.

Chung, S.-L., Liu, D., Ji, J., Chu, M.-F., Lee, H.-Y., Wen, D.-J., Lo, C.-H., Lee, T.-Y., Qian, Q., and Zhang, Q., 2003, Adakites from continental collision zones: Melting of thickened lower crust beneath southern Tibet: Geology, v. 31, p. 1021-1024, doi: 10.1130/G19796.1.

Chung, S.-L., Chu, M.-F., Zhang, Y., Xie, Y., Lo, C.-H., Lee, T.-Y., Lan, C.-Y., Li, X., Zhang, Q., and Wang, Y., 2005, Tibetan tectonic evolution inferred from spatial and temporal variations in post-collisional magmatism: Earth Science Reviews, v. 68, p. 173-196, doi: 10.1016/j.earscirev.2004.05.001

Coulon, C., Maluski, H., Bollinger, C., and Wang, S., 1986, Mesozoic and Cenozoic volcanic rocks from central and southern Tibet: ${ }^{40} \mathrm{Ar} /$ ${ }^{39} \mathrm{Ar}$ dating, petrological characteristics and geodynamic implications: Earth and Planetary Science Letters, v. 79, p. 281-302, doi: 10.1016/0012-821X(86)90186-X.

Debon, F., Le Fort, P., Sheppard, S.M.F., and Sonet, J., 1986, The four plutonic belts of the transHimalaya: A chemical, mineralogical, isotopic and chronological synthesis along a Tibet-
Nepal section: Journal of Petrology, v. 27, p. 219-250.

Griffin, W.L., Wang, X., Jackson, S.E., Pearson, N.J., O'Reilly, S.Y., Xu, X., and Zhou, X., 2002, Zircon chemistry and magma mixing, SE China: In-situ analysis of Hf isotopes, Tonglu and Pingtan igneous complexes: Lithos, v. 61 , p. $237-269$, doi: $10.1016 / \mathrm{S} 0024-$ 4937(02)00082-8.

Harris, N.B.W., Inger, S., and Xu, R., 1990, Cretaceous plutonism in Central Tibet: An example of post-collision magmatism?: Journal of Volcanology and Geothermal Research, v. 44, p. 21-32, doi: 10.1016/0377-0273(90)90009-5.

Hoskin, P.W.O., and Black, L.P., 2000, Metamorphic zircon formation by solid-state recrystallization of protolith igneous zircon: Journal of Metamorphic Geology, v. 18, p. 423-439, doi: 10.1046/j.1525-1314.2000.00266.x.

Kapp, J.L.D., Harrison, T.M., Kapp, P., Grove, M., Lovera, O.M., and Lin, D., 2005a, Nyainqentanglha Shan: A window into the tectonic, thermal, and geochemical evolution of the Lhasa block, southern Tibet: Journal of Geophysical Research, v. 110, p. B08413, doi: 10.1029/2004JB003330.

Kapp, P., Yin, A., Harrison, T.M., and Ding, L., 2005b, Cretaceous-Tertiary shortening, basin development, and volcanism in central Tibet: Geological Society of America Bulletin, v. 117 , p. $865-878$, doi: 10.1130/B25595.1.

Liang, Y.-H., Chung, S.-L., Liu, D., O'Reilly, S.Y., Chu, M.-F., Ji, J., Song, B., and Pearson, N.J. 2004, Detrital zircon study along the Tsangpo River, SE Tibet: Eos (Transactions, American Geophysical Union), v. 85, abs. T53A-0466.

Pan, G., Ding, J., Yao, D., and Wang, L., compilers, 2004, Guidebook of 1:1,500,000 geologic map of the Qinghai-Xizang (Tibet) plateau and adjacent areas: Chengdu, China, Chengdu Cartographic Publishing House, 48 p.

Pearce, J.A., and Mei, H., 1988, Volcanic rocks of the 1985 Tibet Geotraverse: Lhasa to Golmud: Royal Society of London Philosophical Transactions, ser. A, v. 327, p. 169-201.

Wen, D.-J., Chung, S.-L., Liu, D., Ji, J., Chu, M.F., Song, B., Lo, C.-H., and Lee, T.-Y., 2003, New SHRIMP U-Pb zircon ages from the Gangdese batholith and implications for the trans-Himalayan magmatic evolution: Geophysical Research Abstracts, v. 5, p. 494.

Wen, D.-J., Chung, S.-L., Song, B., Ji, J., Liu, D. Qian, Q., Chu, M.-F., and Lo, C.-H., 2005, The Gangdese Batholith: Ages, geochemical characteristics and geodynamic implications: 2nd National Conference on Petrology and Geodynamics Abstracts, Hangzhou, China, p. 339

Xu, R., Scharer, U., and Allègre, C.J., 1985, Magmatism and metamorphism in the Lhasa Block (Tibet): A geochronological study: Journal of Geology, v. 93, p. 41-57.

Yin, A., and Harrison, T.M., 2000, Geologic evolution of the Himalayan-Tibetan orogen: Annual Review of Earth and Planetary Sciences, v. 28 , p. 211-280, doi: 10.1146/annurev. earth.28.1.211.

Yin, J., and Grant-Mackie, J.A., 2005, Late TriassicJurassic bivalves from volcanic sediments of the Lhasa block, Tibet: New Zealand Journal of Geology and Geophysics, v. 48, p. $555-576$.

Zhang, K.-J., Xia, B.-D., Wang, G.-M., Li, Y.-T., and Ye, H.-F., 2004, Early Cretaceous stratigraphy, depositional environments, sandstone provenance, and tectonic setting of central Tibet: Geological Society of America Bulletin v. 116 , p. 1202-1222, doi: 10.1130/B25388.1.

Manuscript received 20 February 2006

Revised manuscript received 11 April 2006

Manuscript accepted 14 April 2006

Printed in USA 